\title{
QUALITY AND CONDITION OF WHEAT GRAIN (Triticum spp.) DURING STORAGE
}

\author{
S. Rakići ${ }^{*}$, S. Janković ${ }^{2}$, M. Demin ${ }^{1}$, D. Bucalo ${ }^{1}$, M. Maslovarić ${ }^{2}$ \\ ${ }^{1}$ University of Belgrade, Faculty of Agriculture, Nemanjina 6, 11080 Zemun-Belgrade, Serbia \\ ${ }^{2}$ Institute of Science Application in Agriculture, Bulevar Despota Stefana 68b, 11000 Belgrade, \\ Serbia \\ Corresponding author: Sveto Rakić, e-mail: sveto@agrif.bg.ac.rs \\ Original scientific paper
}

\begin{abstract}
The effect of storage on quality and condition of grain of three wheat cultivars (Ljiljana, Dragana and Simonida) selected in Serbia, was studied. Freshly harvested wheat was stored at $25^{\circ} \mathrm{C}$ for 12 and 20 months. Decreasing of the volume from 812.3 to $727.7 \mathrm{kgm}^{-3}$ and absolute mass from 38.5 to $33.0 \%$ of wheat grain during storage was recorded. Grain germination in interaction of storage duration and temperature remained at the level above $95 \%$. The interaction of studied factors exhibited no statistically significant effect on the changes in the degree of germination of wheat grain. The changes of the acid degree value (2.0 $2.4 \mathrm{ml} 1(\mathrm{NaO}) / 100 \mathrm{~g})$ were at the level of statistical significance. $\mathrm{pH}$ value of fresh samples of grain was 6.5 and after 20 months 5.5. The samples tested from the aspect of their glassiness were homogenous, the value of the coefficient of variation for storage duration was $\mathrm{CV}<10 \%$, and for genotypes $\mathrm{CV}<18 \%$. The storage duration of wheat grain mostly contributed to the increase of the acid degree value, and slightly less the genotype, as well as the interaction of these factors.
\end{abstract}

Key words: wheat grain, storage effect, quality.

\section{Introduction}

Wheat grain, as well as corn and rice, is dominant in global agricultural production. This plant species is particularly adjusted to moderate climatic conditions and regions, with the yield of over 10 tha $^{-1}$ in some agronomic systems (FAOSTAT, http://faostat.fao.org/default.aspx). The largest quantities are processed for use in human nutrition, however, smaller quantities are used in animal nutrition or non-food purposes (protein-based films, starch-based plastics) (Colonna and Guilbert, 1999). Previous studies have been mainly focused on the utilization value 
(Stanković et al., 2011) of small grains as a source of fast fermenting energy (Vasilachil et al., 2010). In available literature, studies can be found of the effect of temperature, air humidity and storage duration on significant losses of nutrients of grains (Shah et al., 2002). Grain can be stored temporarily and for a longer period of time (one or several years). Major conditions of proper storage during entire period are air humidity and temperature. Recently, wheat grain is stored in conditions of very low air humidity (below critical 14.5\%) or in conditions in the absence of air or lowering of temperature to the point when all life functions of grain cease (Žeželj, 1995). Changes of physical characteristics of wheat grain during storage have also been studied (Kent and Evers, 1994). A study (Rehman, 2006) dealing with the investigation of the effect of storage conditions on nutritive properties of wheat, corn and rice has come to the results indicating significant changes of the physical-chemical parameters of the tested samples. The objective of the present study was to assess the impact of storage duration and temperature on some physical, biological and chemical properties of wheat grain.

\section{Materials and Methods}

The tested wheat genotypes are commercial cultivars (Table 1) selected at the Institute of Field and Vegetable Crops in Novi Sad and recorded in the Registry of cultivars of Republic of Serbia. The material used in the analysis was produced on the experimental field Rimski Šančevi in year 2010. The laboratory samples were formed of freshly harvested grain using standard methods for sampling of grain cultures (ISO 24333 : 2009) as well as adequate ICC standards and AACC methods. All samples were protected from insects without the use of any chemicals. Approximately 500g of each tested cultivar with $11-13 \%$ of moisture was placed in closed plastic dishes of uniform volume. The identified samples were stored at a controlled temperature of $25^{\circ} \mathrm{C}$ for 12 and 20 months. Three dishes of each treatment were randomly selected at the end of defined period of time and their contents were mixed and tested in order to assess the quality and status of samples.

Table 1. Tested wheat genotypes

\begin{tabular}{|l|c|c|}
\hline Genotype & Registration year & Pedigree \\
\hline Ljiljana & 2000 & NS-3287-3/Rodna \\
\hline Dragana & 2002 & Sremka 2/Francuska \\
\hline Simonida & 2003 & NS 63-25/Rodna//NS-3288 \\
\hline
\end{tabular}

For assessment of the quality and state of tested wheat grain samples, physical properties (absolute mass, volume mass, glassiness and mealy 
breakdown), biological properties (germination ability) and chemical properties (acid degree value and $\mathrm{pH}$ ) were determined using standard procedures and methods of analysis (Kaluđerski and Filipović, 1998; AOAC, 1990). $\mathrm{pH}$ value was determined in the filtrate of $2 \mathrm{~g}$ of crushed sample ( $1 \mathrm{~mm}$ mesh size) in $20 \mathrm{ml}$ of distilled water using glass electrode $\mathrm{pH}$ meter (Hanna, HI83141, Instruments USA). In order to reach the objective conclusions on the effect of the observed factors on the studied wheat grain properties, as well as the possibility of application of parameter tests (ANOVA and LSD-test), the homogeneity of variances was tested using the Levene's test. The results of these tests indicated that variances of samples in regard to almost all studied properties were homogenous, except variances in the volume mass of wheat grain (Table 2). Because the homogeneity was not respected, the statistical significance for higher level of risk (1\%) was observed.

Table 2. Levene's test of samples

\begin{tabular}{|l|c|c|}
\hline Properties & F & p-level \\
\hline Glassiness and mealy breakdown & 1.551 & 0.2092 \\
\hline Acid degree value & 2.601 & 0.0505 \\
\hline Volume mass & 5.892 & 0.0009 \\
\hline Germination ability & 1.606 & 0.1921 \\
\hline Absolute mass & 13.631 & 0.0000 \\
\hline $\mathrm{pH}$ & 4.058 & 0.0065 \\
\hline
\end{tabular}

The study of the differences among genotypes and storage duration, as well as their interaction, was carried out by a two-factorial analysis of variance (ANOVA) as well as LSD- test for the level of risk of $5 \%$ and 1\% (Hadživuković, 1977). The magnitude of the influence of each factor, as well as their interactions, was determined by partial eta square coefficient subsequently classified according to Cohen's gradation (Cohen, 1988). Eta partial coefficients $\left(\eta^{2}\right)$ measure a relationship between sum of square (SS) between factors and difference between SS total and SS error from analysis of variance $\left(\eta^{2}=\right.$ SS between $/$ SS total + SS error). The relative correlation between the properties was measured with the Pearson's correlation coefficient, at the significance level of $5 \%$ and $1 \%$. Experimental data were processed using statistical package STATISTICA 10 for Windows (StatSoft).

\section{Results and Discussion}

The investigated properties of wheat grain in the analysed samples depending on the duration and temperature of storage are presented in the Table 3. $\mathrm{pH}$ values of the analysed samples were homogenous $(\mathrm{CV}<7 \%)$. The highest recorded value was on fresh grain samples and the lowest on grain after 20 months 
of storage. The recorded differences in $\mathrm{pH}$ value between these two time intervals show a statistical significance $(\mathrm{p}<0.05)$. The samples of grain of the observed genotypes had various $\mathrm{pH}$ values. The genotype Ljiljana had a statistically significantly higher $\mathrm{pH}$ value of grain compared to the genotype Simonida $(p<0.05)$. Eta partial coefficients also show very high effect of the storage duration on the $\mathrm{pH}$ value of wheat grain, $\eta^{2}=0.9342$ (Table 4). Also, the interaction of factors in addition to the statistical significance has high effect on the observed occurrence $\left(\eta^{2}=0.5507\right)$.

Samples analyses in terms of the glassiness showed homogeneity, while the coefficients of variations for storage duration and for genotypes were less than $10 \%$ and $18 \%$, respectively. The highest glassiness of wheat grain was recorded at the beginning of grain storage period $(78.1 \%)$. After one year it was $63.5 \%$, and after 20 months of storage $55.6 \%$. Therefore, with the storage duration, the glassiness of what grain has been decreasing. The observed differences were very significant $(p<0.05)$. The investigated wheat genotypes expressed various values of wheat glassiness. Therefore, the genotype Simonida had the highest value recorded for this property $(71.2 \%)$, followed by the genotype Dragana $(66.4 \%)$, and the genotype Ljiljana $59.5 \%$. The interaction of the storage duration and the genotype had no significant contribution to the change of glassiness in wheat grain. Eta partial coefficients also showed very high effect of the factor on the change of glassiness in wheat grain $\left(\eta^{2}=0.9703\right.$ and $\left.\eta^{2}=0.8968\right)$, but the effect of storage duration had stronger impact than the genotype.

Table 3. The effect of storage duration (months) (A) and genotypes (B) on the studied wheat properties

\begin{tabular}{|c|c|c|c|c|c|}
\hline Factor & $\mathrm{pH}$ & Glassiness (\%) & Volume mass $\left(\mathrm{kgm}^{-3}\right)$ & $\begin{array}{c}\text { Germination } \\
(\%)\end{array}$ & $\begin{array}{l}\text { Absolute } \\
\text { mass }(\mathrm{g})\end{array}$ \\
\hline $\begin{array}{c}\text { (A) } \\
0 \\
12 \\
20\end{array}$ & $\begin{array}{l}6.5^{\mathrm{a}} \pm 0.022 \\
6.2^{\mathrm{b}} \pm 0.056 \\
5.5^{\mathrm{c}} \pm 0.043\end{array}$ & $\begin{array}{l}78.1^{\mathrm{a}} \pm 1.30 \\
63.5^{\mathrm{b}} \pm 2.16 \\
55.6^{\mathrm{c}} \pm 1.92\end{array}$ & $\begin{array}{l}812.3^{\mathrm{a}} \pm 2.23 \\
773.3^{\mathrm{b}} \pm 5.86 \\
727.7^{\mathrm{c}} \pm 7.98\end{array}$ & $\begin{array}{c}96.8^{\mathrm{ab}} \pm 0.48 \\
97.1^{\mathrm{a}} \pm 0.80 \\
95.1^{\mathrm{b}} \pm 0.53\end{array}$ & $\begin{array}{l}38.5^{\mathrm{a}} \pm 0.60 \\
33.8^{\mathrm{b}} \pm 1.13 \\
33.0^{\mathrm{b}} \pm 0.49\end{array}$ \\
\hline $\begin{array}{c}\text { (B) } \\
\text { Ljiljana } \\
\text { Simonida } \\
\text { Dragana }\end{array}$ & $\begin{array}{l}6.1^{\mathrm{a}} \pm 0.160 \\
6.0^{\mathrm{b}} \pm 0.129 \\
6.1^{\mathrm{ab}} \pm 0.142\end{array}$ & $\begin{array}{l}59.5^{\mathrm{c}} \pm 3.69 \\
71.2^{\mathrm{a}} \pm 3.15 \\
66.4^{\mathrm{b}} \pm 3.22\end{array}$ & $\begin{array}{c}776.9^{\mathrm{b}} \pm 12.6 \\
785.1^{\mathrm{a}} \pm 9.29 \\
751.2^{\mathrm{c}} \pm 15.08\end{array}$ & $\begin{array}{l}96.3^{\mathrm{a}} \pm 0.66 \\
95.8^{\mathrm{a}} \pm 0.80 \\
96.8^{\mathrm{a}} \pm 0.56\end{array}$ & $\begin{array}{c}36.5^{\mathrm{a}} \pm 1.00 \\
35.1^{\mathrm{ab}} \pm 0.32 \\
33.8^{\mathrm{b}} \pm 3.22\end{array}$ \\
\hline
\end{tabular}

* Means in columns followed by the same letter are not significantly different according to Fisher's protected LSD values $(\mathrm{P}=0.05)$

The analysed samples expressed considerable homogeneity in regard to the value of the volume mass since coefficients of variation had a value below $3 \%$. The 
volume mass of fresh samples of wheat grain was the highest $\left(812.3 \mathrm{kgm}^{-3}\right)$, and it has been decreasing with the extension of the storage time. The recorded differences between the storage intervals were statistically significant $(p<0.05)$. Between the observed three genotypes there is a statistically significant difference $(\mathrm{p}<0.05)$ in volume mass, ranging from $785.1 \mathrm{kgm}^{-3}$ in the genotype Simonida to $751.2 \mathrm{kgm}^{-3}$ in the genotype Dragana. The interaction between the factors exhibited significant effect on the change of volume mass of wheat grain $(p<0.05)$. Eta partial coefficients also showed very high and uniform effect of the factors and the interaction on the change in volume mass of wheat grain $\left(\eta^{2}=0.9971, \eta^{2}=0.9835\right.$ and $\eta^{2}=0.9479$ ).

The factors, storage duration and genotype, reflected their action on the change in the germination ability of wheat grain. Therefore, the highest germination ability was recorded in grain after 12 months of storage (97.1\%), and the lowest after 20 months of storage $(95.1 \%)$. The grain germination ability after 12 months of storage was statistically significantly higher than after 20 months of storage $(\mathrm{p}<0.01)$, but no significant differences were determined in comparison to the grain germination ability at the beginning of storage $(p>0.05)$. The germination ability of grain of various wheat genotypes showed no significant differences $(\mathrm{p}>0.05)$. The calculated partial eta-squared coefficient for storage duration indicated that it influences with $25 \%$ the germination ability of wheat grain.

Changes in the absolute mass of wheat grain depending on the storage duration and genotypes are presented in the Table 3 . The variability of absolute mass depending on the storage duration of wheat grain is below $10 \%$, and between the genotypes less than $14 \%$. With the increase of storage duration, the absolute mass has been decreasing. Fresh grain samples had a statistically significantly higher value of absolute mass compared to the stored samples (12 and 20 months) $(p<0.05)$. However, the difference between grain samples after 12 and 20 months of storage was not significant $(\mathrm{p}>0.05)$.

Table 4. Partial eta-squared coefficients

\begin{tabular}{|l|c|c|c|}
\hline Property & Storage duration & Genotype & Interaction \\
\hline $\begin{array}{l}\text { Glassiness and mealy } \\
\text { breakdown }\end{array}$ & 0.9703 & 0.8968 & 0.3084 \\
\hline Acid degree value & 0.9159 & 0.8345 & 0.4529 \\
\hline Volume mass & 0.9971 & 0.9835 & 0.9479 \\
\hline Germination ability & 0.2526 & 0.0659 & 0.2015 \\
\hline Absolute mass & 0.7046 & 0.3157 & 0.3685 \\
\hline $\mathrm{pH}$ & 0.9342 & 0.2538 & 0.5507 \\
\hline
\end{tabular}

The genotype Ljiljana had grain of the highest absolute mass $(36.5 \mathrm{~g})$, statistically significantly higher compared to the genotype Dragana $(33.8 \mathrm{~g})$. The 
absolute mass of grain of the genotype Simonida showed no statistically significant difference to other two genotypes ( $>00.05$ ). The observed factors had not only a statistically very significant effect on the change of absolute grain mass, but also very high effect of their action, as indicated by the values of partial eta-squared coefficients $\left(\eta^{2}=0.7046\right.$ and $\left.\eta^{2}=0.3157\right)$, except that the effect of storage duration had stronger effect than genotype.

Figure 1 illustrates changes in the acid degree value of the studied wheat grain genotypes depending on the storage duration. The variability of the analysed samples which accompanies the value of the acid degree value of wheat grain was not exhibited for storage duration $(\mathrm{CV}<6.2 \%)$, or genotypes $(\mathrm{CV}<9 \%)$.

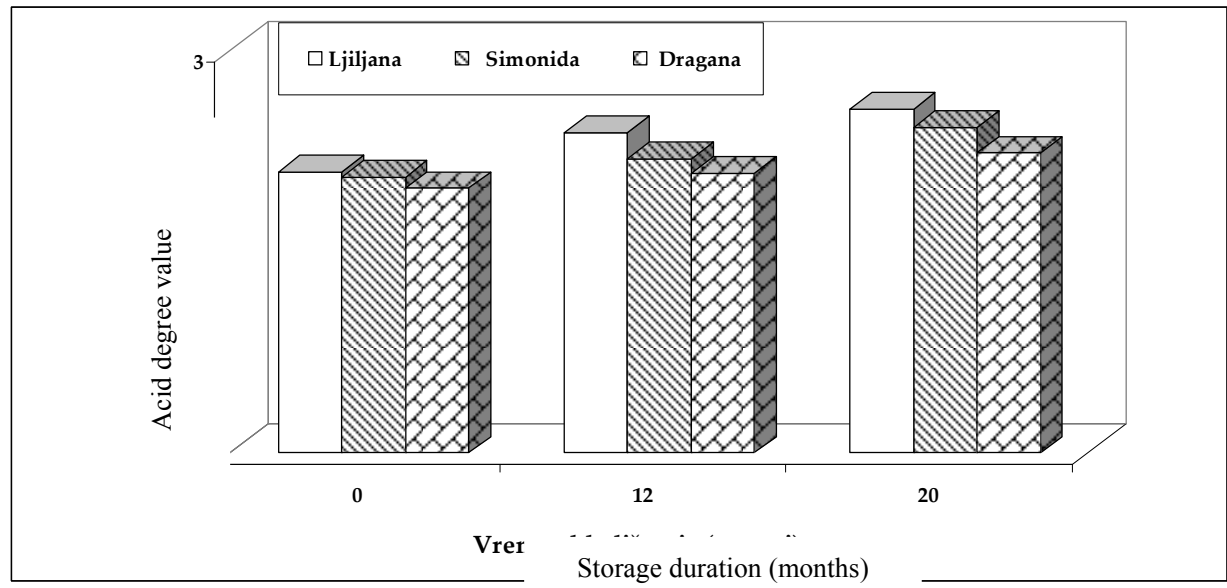

Figure 1 Acid degree value depending on the genotype and storage duration of wheat grain

Storage duration of wheat grain significantly influences the increase of the acid degree value. At the beginning of storage, the acid degree value was $2.03 \mathrm{ml}$ $1(\mathrm{NaO}) / 100 \mathrm{~g}$, after 12 months $2.21 \mathrm{ml} 1(\mathrm{NaO}) / 100 \mathrm{~g}$, and after 20 months it was $2.404 \mathrm{ml} 1(\mathrm{NaO}) / 100 \mathrm{~g}$. The recorded differences in the acid degree value between the studied storage intervals were statistically highly significant $(\mathrm{p}<0.01)$. The acid degree value of wheat grain also differed significantly between genotypes. The genotype Ljiljana had an acid degree value $(2.344 \mathrm{ml} 1(\mathrm{NaO}) / 100 \mathrm{~g})$ that was significantly higher compared to the genotype Simonida $(2.219 \mathrm{ml} 1(\mathrm{NaO}) / 100 \mathrm{~g})$ and Dragana $(2.219 \mathrm{ml} 1(\mathrm{NaO}) / 100 \mathrm{~g}), \mathrm{p}<0.01$. The genotype Dragana had a significantly lower acid degree value in comparison to the other two genotypes $(\mathrm{p}<0.01)$. The relative correlation of the acid degree value (Figure 1) and $\mathrm{pH}$ of wheat grain is negative and medium strong, but statistically very significant $(\mathrm{r}=$ $\left.0.647^{* *}\right)$. In other words, with the increase of value of one indicator, the other indicator decreases, and vice versa. Eta partial coefficients also show very strong influence of the factors on the acid degree value of wheat grain (Table 4). This indicates that the storage duration and genotypes not only have statistically 
significant effect on the acid degree value, but that their effect according to Cohen's gradation is exceptionally high $\left(\eta^{2}=0.9159\right.$ and $\left.\eta^{2}=0.8345\right)$.

\title{
Conclusion
}

Storage during different periods of time at the temperature of $25^{\circ} \mathrm{C}$ had negative effect on quality and condition of wheat grain. Decreasing of the values of volume and absolute mass are registered. In addition, gradual diminishing of the germination ability is noticeable, which, however, remained at very high level of over $95 \%$. The samples tested for the glassiness were homogenous, the value of coefficient of variation for storage duration was $\mathrm{CV}<10 \%$, and for genotypes $\mathrm{CV}<18 \%$. Changes in the acid degree value $(2.0-2.4 \mathrm{ml} 1(\mathrm{NaO}) / 100 \mathrm{~g})$ and $\mathrm{pH}$ (6.5 - 5.5) were significant, which was expected considering that these properties reflect the condition, i.e. freshness of the wheat. The relative correlation of the acid degree value and $\mathrm{pH}$ of wheat grain is negative and medium strong, but statistically very significant $\left(\mathrm{r}=-0.647^{* *}\right)$. In other words, with the increase of value of one indicator, the other indicator decreases, and vice versa. The occurred changes were obvious, but not extreme. Grain retained all its functional properties. Based on presented results, storage of wheat grain under these conditions can be recommended, especially in cases when grain is exported to southern regions where average temperatures are higher and need for food is more pronounced. In future, it is necessary to extend these studies to detailed study of the chemical composition of wheat grain and their status during storage.

\section{Acknowledgment}

The research was financed by the Ministry of Education, Science and Technological Development, Republic of Serbia, project TR 31066.

\section{Kvalitet i stanje semena pšenice (Triticum spp.) tokom skladištenja}

\author{
S. Raki S. Janković, M. Demin, D. Bucalo, M. Maslovarić
}

\section{Rezime}

Ispitivan je uticaj skladištenja na kvalitet i stanje semena pšenice za tri sorte (Ljiljana, Dragana i Simonida) koje su selekcionisane u Srbiji. Posle žetve pšenica je uskladištena na $25^{\circ} \mathrm{C}$ za 12 i 20 meseci. Zabeležen je pad vrednosti zapreminske 812,3-727,7 $\mathrm{kgm}^{-3}$ i apsolutne mase 38,5 - 33,0\% tokom skladištenja semena pšenice. Klijavost semena $u$ interakciji vremena i temperature skladištenja se 
zadržala na nivou preko 95\%. Interakcija ispitivanih faktora nije ispoljila statistički značajan uticaj na promenu stepena klijavosti semena pšenice. Promene kiselinskog stepena $(2,0-2,4 \mathrm{ml} 1(\mathrm{NaO}) / 100 \mathrm{~g})$ su na nivou statističke značajnosti. pH vrednost svežih uzoraka semena je bila 6,5 a nakon 20 meseci 5,5. Uzorci testirani na svojstvo staklavosti su veoma homogeni, vrednost koeficijenata varijabilnosti za dužinu skladištenja je $\mathrm{Cv}<10 \%$, a za genotipove $\mathrm{Cv}<18 \%$. Dužina skladištenja semena pšenice najviše doprinosi porastu vrednosti kiselinskog stepena, a nešto manje genotip, kao i interakcija ovih faktora.

\section{References}

AOAC, 1990 Association of Official Analytical Chemists (AOAC). (1990). Official methods of analysis (14th ed.). Washington DC, USA: Association of Official Analytical Chemists.

COLONNA, P., GUILBERT, S., (1999): Biopolymer Science: Food and Non Food Applications. Montpellier, France, 28-30 September 1998. INRA, Paris.

COHEN J.W. (1988): Statistical power analysis for the behavioral sciences (2nd edn).

HADŽIVUKOVIĆ S. (1977): Planiranje eksperimenata, Privredni pregled, Beograd.

ISO 24333:2009, Cereals and cereal products - Sampling.

KALUĐERSKI G., FILIPOVIĆ N. (1998) Methods of analysis grain quality. University of Novi Sad, Novi Sad.

KENT N.L. and EVERS A.D. (1994): Technology of Cereals British Library, ISBN 0080408338.

REHMAN Z.U. (2006): Storage effects on nutritional quality of commonly consumed cereals. Food Chemistry, 95, 53-57.

SHAH W.H., REHMAN Z.U., KAUSAR T., HUSSAIN A. (2002): Storage of wheat with ears Pakistan. Journal of Scientific and Industrial Research, 17, 206-209.

STANKOVIĆ S., LEVIĆ J., KRNJAJA V. (2011): Fumonisin $\mathrm{B}_{1}$ in maize, wheat and barley grain in Serbia. Biotechnology in Animal Husbandry 27,3, 631-641.

STATISTICA v. 10.0 (2010): StatSoft. University Licence, University of Novi Sad, Serbia.

VASILACHIL A., POP S., DRAGOMIR C., VLASSA M., FILIP M. (2010): The influence of replacing slow with rapid starch in growing rams' diets on the level of rumen microbial proteosynthesis. Biotechnology in Animal Husbandry 26,5-6, 339-346.

ŽEŽELJ M. (1995): Tehnologija žita i brašna poznavanje čuvanje i prerada žita. Tehnološki fakultet Novi Sad. 